\title{
Isolation and Partial Characterization of a Specific Alpha-Fetoprotein Receptor on Human Monocytes
}

Yuji Suzuki, Carl Q. Y. Zeng, and Elliot Alpert*

Gastroenterology Division, Department of Medicine, and Lady Davis Institute for Medical Research, Sir Mortimer B. Davis-Jewish General Hospital and McGill University, Montreal, Quebec H3T IE2, Canada

\begin{abstract}
Since a large body of data has suggested a significant role for alpha-fetoprotein (AFP) in the regulation of the immune response at a number of levels, we examined the possibility of a specific receptor for AFP on the immune recognition cell, the monocyte/macrophage. Microscopic autoradiography exhibited an obvious binding of AFP almost exclusively on human peripheral monocytes but not on lymphocytes. In a human monocyte cell line (U937) Scatchard plot analysis indicated the presence of two distinct AFP-specific binding sites with a $K_{\mathrm{d}}$ of $5 \times 10^{-11} \mathrm{M}, 49$ binding sites per cell, and $2.5 \times 10^{-7} \mathrm{M}$, 7,800 binding sites per cell. ${ }^{125}$ I-ASD-AFP, AFP-radiolabeled bifunctional photoactivatable thio-cleavable cross-linker, was used to isolate the AFP binding protein from U937 cells. After ultraviolet photoactivation, ${ }^{125}$ I-sulfosuccinimidyl 2 -( $p$-azidosalicylamido)ethyl-1,3'-dithiopropionate was covalently linked to the putative receptor. Autoradiography of SDS gradient PAGE under reducing conditions showed a major radiolabeled band at between 62 and $65 \mathrm{kD}$. To confirm the specificity of the finding, recombination of AFP with the isolated receptor was examined in artificially reconstituted membrane vesicles, which also resulted in a single band at $\sim 62-65 \mathrm{kD}$ by SDSPAGE autoradiography. From the data above, we concluded that human monocytes possess a specific AFP binding protein on the membrane, a putative receptor, which may be involved with the physiological regulation of the immune response. $(J$. Clin. Invest. 1992. 90:1530-1536.) Key words: immunoregulation • human monocytic cell line • soluble cell surface protein • reconstituted membrane vesicles $\bullet$ Scatchard analysis
\end{abstract}

\section{Introduction}

Alpha-fetoprotein (AFP) ${ }^{1}$ is the predominant serum globulin in early fetal life and is synthesized mainly by the yolk sac and fetal liver. However, AFP can be detected in a variety of cells and tissues other than the yolk sac and liver during ontogenesis $(1,2)$, presumably because AFP is internalized into these cells or tissues but not synthesized there. Uriel and colleagues have

Address correspondence to Elliot Alpert, M. D., Department of Medicine, Sir Mortimer B. Davis-Jewish General Hospital and McGill University, 3755 Côte Sainte Catherine Road, Montreal H3T 1E2, Quebec, Canada. 1992.

Received for publication 28 May 1991 and in revised form 11 May

1. Abbreviations used in this paper: AFP, alpha-fetoprotein; SASD, sulfosuccinimidyl 2-(p-azidosalicylamido)ethyl-1,3'-dithiopropionate.

J. Clin. Invest.

(C) The American Society for Clinical Investigation, Inc.

$0021-9738 / 92 / 10 / 1530 / 07 \$ 2.00$

Volume 90, October 1992, 1530-1536 been demonstrated the specific uptake of AFP by certain malignant cells (3-5). They have shown kinetic analysis for putative receptors on blast transformed lymphocytes as well as on a murine $\mathrm{T}$ lymphoma cell line, but not on normal resting lymphocytes $(6,7)$. In these reports, the authors suggested that AFP and AFP receptors may regulate the transfer of polyunsaturated fatty acids into cells undergoing growth and proliferation.

In addition, numerous studies have documented the effects of AFP on various aspects of the immune function and have suggested that it plays an important immunoregulatory role. Previous studies have demonstrated inhibition of natural killer cell activity (8), the induction of T suppressor cells (9-11) the inhibition of mitogenic responses to PHA and Con A (12-15), the inhibition of $\mathrm{T}$ cell proliferation to Ia determinants (16), decreased macrophage phagocytosis $(17,18)$, and decreased macrophage Ia expression $(19,20)$. Thus, the present study was undertaken to determine if the effects of AFP on immune function was mediated by a cell surface receptor on the immune recognition cell, the monocyte/macrophage. It has been reported that human monocytes/macrophages express receptor activities to a number of essential substances, including $\operatorname{IgG-Fc}(21,22)$, interleukin 1 (23), interleukin 3(24), C-reactive protein (25), tumor necrosis factor $(26), \operatorname{IgE}-F c(27,28)$, maleyl-albumin $(29,30)$, transferrin $(31)$, ceruloplasmin (32), and urokinase (33). It is notable that the identity of an identical Fc receptor on both peripheral monocytes and monocyte cell line (U937) was documented (34), enabling further study due to the great convenience, as well as the defined characteristics of this established monocytic cell line. Also, AFP was demonstrated in macrophages in amniotic fluids with neural tube defects (35) and in granulomatous inflammation of the mouse (36).

In this report, we demonstrate specific binding of AFP on a human monocyte cell line, and partially characterize an AFP binding protein, the putative AFP receptor.

\section{Methods}

Materials. Sulfosuccinimidyl 2-( $p$-azidosalicylamido)ethyl-1,3'-dithiopropionate (SASD) and Iodogen were purchased from Pierce Chemical Co., (Rockford, IL) ${ }^{125}$ Iodine was obtained from New England Nuclear (Boston, MA). Human AFP was purified from human amniotic fluid by immuno-affinity column chromatography and Sephadex G200 (Pharmacia LKB Biotechnology, Piscataway, NJ) column separation. Purified AFP showed a single band on SDS-PAGE, a single peak on $\mu$ Bondapak C18 (Millipore Corp., Milford, MA) HPLC column, and no reaction to anti-human serum. U937, a human monocytic cell line, was obtained from American Type Culture Collection (Rockville, MD) and maintained in tissue culture medium RPMI 1640 , supplemented with $10 \%$ newborn calf serum and $1 \%$ Glutamin. THP-1, an acute monocytic leukemia cell line, was also obtained from American Type Culture Collection. All reagents for SDS-PAGE came 
from Bio-Rad Laboratories (Richmond, CA). X-ray films, NTB-2 emulsion, full length D19 developer, and full length rapid fixer for autoradiography were from Kodak.

Microscopic autoradiography of human peripheral monocytes. Purified AFP was radioiodinated by Iodogen method (37). ${ }^{125} \mathrm{I}-\mathrm{AFP}$, with sp act $>5 \mu \mathrm{Ci} / \mu \mathrm{g}$ and with $>90 \%$ of the counts TCA precipitable, was used for microscopic autoradiography and for binding assays. Human peripheral mononuclear cells were isolated from heparinized venous blood by ficoll density centrifugation (Histopaque 1077; Sigma Diagnostics, St. Louis, MO), resuspended in RPMI 1640 without serum, and inoculated into two-chamber slides (Lab-Tek Div., Miles Laboratories Inc., Naperville, IN). After $1 \mathrm{~h}$ culture under $5 \% \mathrm{CO}_{2}$, the cells were washed with Hanks' solution and incubated with ${ }^{125} \mathrm{I}$-AFP at 500 $\mathrm{ng} / \mathrm{ml}$ in each chamber. After the incubation, unbound ligand was washed three times by sequential immersion of the entire slides into $500 \mathrm{ml}$ of PBS, fixed with 3:1 methanol: acetic acid, allowed to air dry, then prepared for the conventional light microscopic autoradiography (38). Human monocytes were identified morphologically as well as by nonspecific esterase staining (kit 90-A1; Sigma Diagnostics).

Binding assay. U937 and THP-1 were cultured in RPMI 1640 for $72 \mathrm{~h}$, washed three times with Hanks' solution before assay. $2.7 \times 10^{6}$ cells, in $200 \mu \mathrm{l}$ of RPMI 1640 final vol, were incubated with different concentrations of ${ }^{125} \mathrm{I}$-AFP in microcentrifuge tubes (Eppendorf Inc., Fremont, CA) for $60 \mathrm{~min}$ with constant end-to-end shaking. Nonspecific binding was determined in the presence of 100 -fold excess of purified unlabeled AFP. Net binding (total binding - nonspecific binding) was similar at $4^{\circ} \mathrm{C}, 22^{\circ} \mathrm{C}$, and $37^{\circ} \mathrm{C}$. Therefore, most studies were performed at room temperature. The separation of free from bound ${ }^{125} \mathrm{I}$ AFP was carried out by layering the cell suspensions on an oil mixture of dibutyl phthalate $(d=1.04)$ and dioctyl phthalate $(d=0.981)$ in a 4:1 ratio $\nabla / \nabla$ in microcentrifuge tubes and spinning the cells at 8,000 rpm for $14 \mathrm{~s}$. Immediately after the separation, the supernatant was carefully removed and the tip, which contained the cell pellet, was cut and the radioactivity counted by gamma counter. Internalization of ${ }^{125} \mathrm{I}$-AFP was determined by eluting the cell-bound ${ }^{125} \mathrm{I}$-AFP with $5 \mathrm{mM}$ acetic acid containing $135 \mathrm{mM} \mathrm{NaCl}$ and $2.5 \mathrm{mM} \mathrm{KCl}$, pH 3.6, sedimenting the washed cell pellet on $10 \%$ sucrose, and solubilizing the cell pellet with $1 \mathrm{~N} \mathrm{NaOH}$. The residual radioactivity solubilized by $\mathrm{NaOH}$ represented the internalized ${ }^{125}$ I-AFP (39).

Radioiodination of SASD-AFP. Microcentrifuge tubes (Eppendorf Inc.) were coated with $40 \mu \mathrm{g}$ of Iodogen in $30 \mu \mathrm{l}$ of methylene chloride and allowed to air dry before use. SASD was dissolved at $1 \mathrm{mg} / 50 \mu \mathrm{l}$ DMSO to which $950 \mu \mathrm{l}$ of $0.2 \mathrm{M}$ borate buffer, $\mathrm{pH} 8.0$, was added (the ratio of solvent to buffer was $1: 20 \mathrm{vol} / \mathrm{vol}$ ). $10 \mu$ l of the dissolved SASD was quickly added to the tube with Iodogen, followed by addition of $200 \mu \mathrm{Ci}$ of $\mathrm{Na}^{125} \mathrm{I}$. After $1 \mathrm{~min}$, the solution was removed from the tube and used for the next conjugation step. Immediately after SASD iodination, the solution was transferred into a tube containing $100 \mu \mathrm{g}$ of purified AFP in $10 \mu \mathrm{l}$ of borate buffer, $\mathrm{pH} 8.0$, and incubated for 60 $\mathrm{min}$ at room temperature. Free ${ }^{125} \mathrm{I}$ and unreacted SASD were removed by applying the reaction mixture to a Sephadex G-25 column (PD-10; Pharmacia LKB Biotechnology Inc., Piscataway, NJ). Cross-linking of the ${ }^{125}$ I-AFP to the SASD was completely inhibitable by prior incubation with unlabeled AFP. The specific radioactivity was always $>0.5$ $\mu \mathrm{Ci} / \mu \mathrm{g}$ AFP.

Cross-linking of ${ }^{125}$ I-SASD-AFP on U937. A vol of $2 \times 10^{8}$ U937 cells was washed with Hanks' solution three times, and preincubated with $2 \%$ polyvinylpyrolidone, mol wt 40,000 , in RPMI for $30 \mathrm{~s}$ to reduce nonspecific binding (40). The cells were subsequently incubated with $50 \mu \mathrm{g}$ of ${ }^{125} \mathrm{I}$-ASD-AFP in a final vol of $2 \mathrm{ml}$ for $30 \mathrm{~min}$ at room temperature. The cells were washed three times with cold PBS to remove free ligand and resuspended in $2 \mathrm{ml}$ of cold PBS. $1 \mathrm{ml}$ of the cell suspension was transferred to a borosilicate glass tube and photoactivated for $2 \mathrm{~min}$ on ice with a high intensity long wave ultraviolet (UV) light (Blak-Ray, San Gabriel, CA) at $100 \mathrm{~W}, 10 \mathrm{~cm}$ from the light source.

Identification of AFP receptor. After ultraviolet irradiation, one aliquot of the cells was washed two times with cold PBS and solubilized with $0.5 \%$ (vol/vol) Triton X-100 in PBS, pH 7.0, containing $0.2 \mathrm{mM}$ PMSF, $0.1 \mathrm{mM}$ EDTA, and 1 trypsin inhibitor unit $/ \mathrm{ml}$ of aprotinin (Sigma Chemical Co.) for $30 \mathrm{~min}$ at $4^{\circ} \mathrm{C}$ with continuous shaking. Another aliquot of nonirradiated cells was submitted directly to solubilization as a control. The cell lysates were centrifuged at $34,000 \mathrm{~g}$ for 30 min to remove nonsolubilized protein, and the supernatants were applied to a hydrophobic absorbent column (Bio-Beads SM-2; Bio-Rad Laboratories) to remove the detergent. The first peak of radioactivity from the eluate was collected and concentrated by a microconcentrator (Centricon 10; Amicon, Beverly, MA). The samples were dissolved in Laemmli buffer (41), separated on a 5-20\% linear gradient SDSPAGE under reducing or nonreducing conditions. After electrophoresis, the gel was fixed with $13.5 \%$ (wt/vol) trichloroacetic acid, $3.5 \%$ (wt/vol) sulfosalicylic acid, and $\mathrm{H}_{2} \mathrm{O}$. The protein bands were visualized by conventional Coomassie brilliant blue staining method. Subsequently, the gel was miniaturized by immersing into $30 \%$ polyethylene

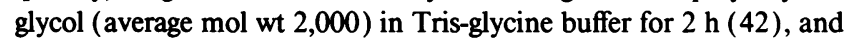
dried carefully by gel dryer. Finally, the radiolabeled protein bands were detected by autoradiography.

All the above procedures before the photoactivation were performed in a photographical dark room under a safe light and the samples were covered by aluminum foil.

Reconstitution of membrane receptor. Recombination of ligand with the isolated receptor was examined in artificially reconstituted membrane vesicles. An aliquot of $2 \times 10^{8}$ U937 cells was prewashed with PBS and sonicated under hypotonic condition (10 mM Hepes buffer, $\mathrm{pH} 7.0$, in the presence of $0.5 \mathrm{mM}$ PMSF, $0.1 \mathrm{mM}$ EDTA, and 1 trypsin inhibitor unit/ml of aprotinin. Crude membrane fractions were obtained by centrifugation of the crushed cells in $60 \%$ sucrose at $400 \mathrm{~g}$ for $30 \mathrm{~min}$, followed by $2,000 \mathrm{~g}$ for $60 \mathrm{~min}$ (43). The method of Kagawa et al. (44) was adopted for the proteoliposome reconstitution system with some modification. Briefly, the membrane fraction was solubilized with $2 \%$ sodium cholate (Sigma Chemical Co.), $2 \%$ soybean lecithin (Calbiochem Corp., La Jolla, CA ) in $1 \mathrm{ml}$ of PBS containing a cocktail of proteolytic inhibitors, as described above, for $30 \mathrm{~min}$ at $4^{\circ} \mathrm{C}$. Unsolubilized membrane residue was removed by centrifugation at $34,000 \mathrm{~g}$ for $30 \mathrm{~min}$ and the supernatant was prepared for further reconstitution studies. Preliminary experiments showed that the supernatant from the membrane fraction of $1 \times 10^{8} \mathrm{U} 937$ cells contained $\sim 500 \mu \mathrm{g}$ of protein measured by BCA protein assay kit (Pierce Chemical Co., Rockford, IL). The incorporation of solubilized membrane proteins into liposomes was carried out by applying this supernatant to Bio-Beads SM-2 column (Bio-Rad Laboratories) (for removal of detergent) instead of extended dialysis. The opaque effluent in the void volume, consisting of reconstituted membrane vesicles, was collected and immediately incubated with $50 \mu \mathrm{g}$ of ${ }^{125} \mathrm{I}$-SASD-AFP for $60 \mathrm{~min}$ at $4^{\circ} \mathrm{C}$ in the dark room. After incubation, bound and free ligands were separated by Sephadex G-200 column $(0.7 \times 50 \mathrm{~cm})$ chromatography under safe light and each fraction was exposed to UV light. After counting the radioactivity, some of the fractions were selected, concentrated, and finally analyzed by SDS-PAGE autoradiography in the same manner as described above. To minimize proteolytic degradation of the receptor protein, both Bio-Beads SM-2 (Bio-Rad Laboratories) and Sephadex G-200 columns were previously equilibrated with PBS containing a cocktail of proteolytic inhibitors.

\section{Results}

Specific binding of AFP to human peripheral monocytes. ${ }^{125} \mathrm{I}-$ AFP was incubated with human peripheral monocytes. A typi$\mathrm{cal}$ and representative autoradiogram is shown in Fig. 1. After 1 $h$ of culture in the absence of serum, the majority of mononuclear cells nonselectively attached to the chamber slides. Nonspecific esterase staining showed that $\sim 15 \%$ were monocytes in all experiments, with the majority of lymphocytes loosely adhering. Silver grains were observed almost exclusively on 


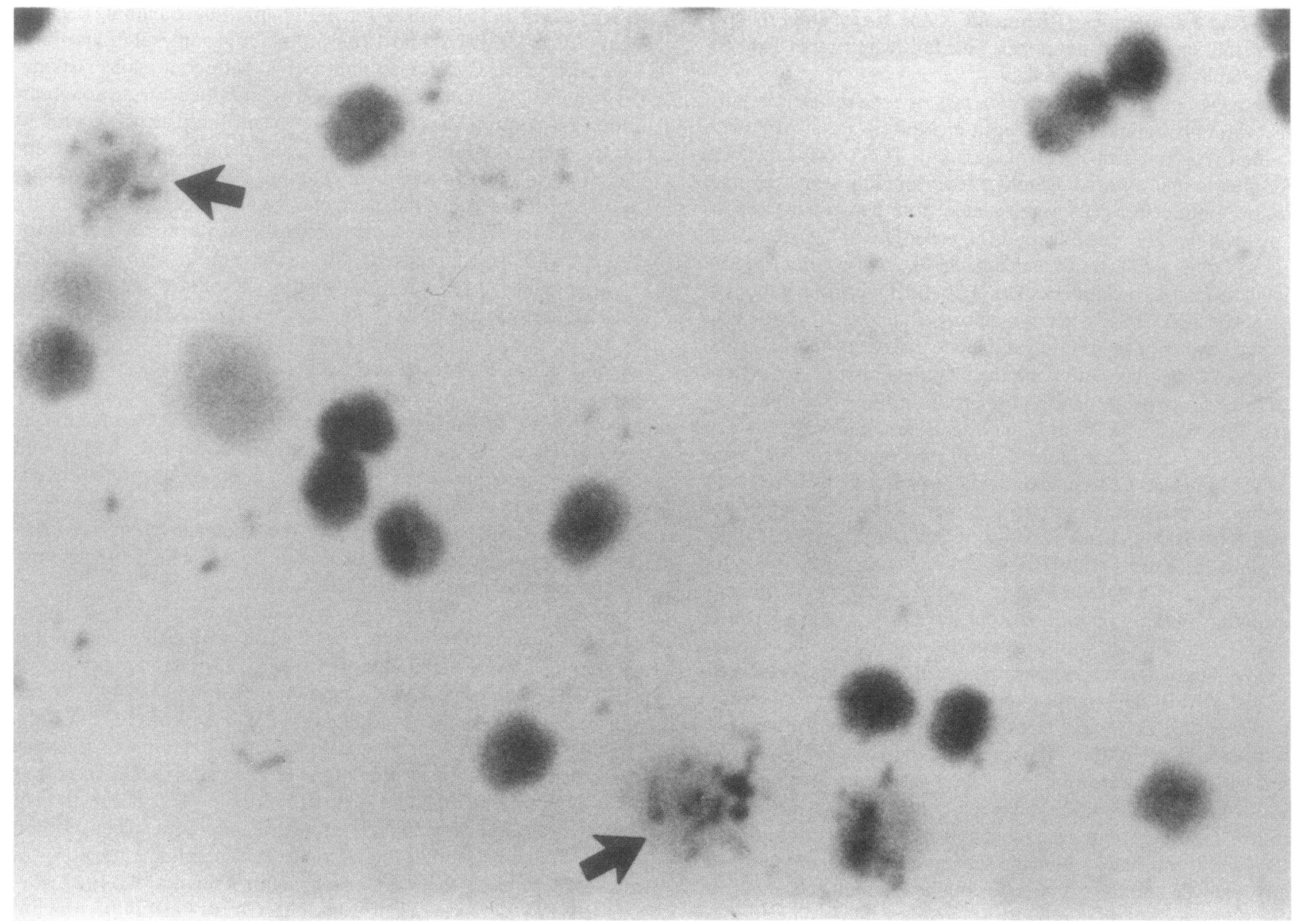

Figure 1. Autoradiogram of human peripheral monocytes incubated with ${ }^{125}$ I-AFP. Human peripheral mononuclear cells were isolated by Ficoll density centrifugation and incubated with $500 \mathrm{ng} / \mathrm{ml}$ of ${ }^{125} \mathrm{I}$-AFP followed by microscopic autoradiography. Nonspecific esterase staining showed $\sim 15 \%$ were monocytes. Silver grains were observed on monocytes (indicated by the arrows) but were virtually undetected on lymphocytes.

monocytes (indicated by the arrows) but were virtually undetected on resting lymphocytes. These data suggested a specificity of AFP binding to monocytes.

Specific binding of AFP to U937 and THP-1. The binding capacity of labeled AFP to both cell lines was further investigated at multiple time points within $60 \mathrm{~min}$ and at AFP concentration ranging from 0.36 to $3,000 \mathrm{ng} / \mathrm{ml}$. AFP binding was completely blocked by the previous addition of unlabeled AFP but not by HSA or human IgG, confirming the specificity of the binding. Preliminary experiments indicated that all AFP binding sites were saturated within $30 \mathrm{~min}$ after incubation at room temperature. The binding curve with U937 showed two saturation plateaus: plateau I ranged from $\sim 0.4$ to $6 \mathrm{ng} / \mathrm{ml}$ and plateau II ranged from about 150 to $3,000 \mathrm{ng} / \mathrm{ml}$ of AFP concentration (Fig. 2, $A$ and $C$ ). Nonspecific binding was $<15 \%$ at any AFP concentration examined.

Dissociation experiments indicated that $\sim 50 \%$ of the total binding was internalized within $60 \mathrm{~min}$ at room temperature (data not shown).

Scatchard plot analysis revealed that plateau I had a $K_{\mathrm{d}}$ of 5 $\times 10^{-11} \mathrm{M}$ and 49 binding sites per cell (Fig. $2 \mathrm{~B}$ ), and plateau II had a $K_{\mathrm{d}}$ of $2.5 \times 10^{-7}$ and 7,800 binding sites per cell (Fig. 2 $D)$. A similar curve was noted in the second monocyte cell line, THP-1, with two plateaus with $K_{\mathrm{d}}$ of $2 \times 10^{-11} \mathrm{M}$, and 1.2 $\times 10^{-9} \mathrm{M}$, in the range of $0.4-5 \mathrm{ng} / \mathrm{ml}$, and $20-100 \mathrm{ng} / \mathrm{ml}$ of AFP concentration, respectively (data not shown).
Identification and reconstitution of AFP receptor. The putative AFP receptor protein was isolated as a major sharp radiolabeled band at $\sim 65 \mathrm{kD}$ by SDS-PAGE under reducing conditions followed by autoradiography (Fig. 3, lane $C$ ). Under nonreducing conditions, a single band was observed at $\sim 50$ $\mathrm{kD}$ (Fig. 3, lane $D$ ). The bands were distinctly different from directly labeled AFP (Fig. 3, lane $A$ ), and were reproducible. The same receptor, with identical molecular mass on SDSPAGE, was identified when the labeled AFP used as ligand was obtained from different sources, as well as when the cell membranes were extracted with different detergents, SDS or Triton $\mathrm{X}-100$. No obvious bands were detected from the samples that had been incubated with ${ }^{125}$ I-SASD-AFP, but that had not been photoactivated (Fig. 3, lane E). As an additional control, ${ }^{125} \mathrm{I}$ ASD-AFP alone was photoactivated in advance and run in the gel, which showed exactly the same mobility as that of unconjugated native ${ }^{125} \mathrm{I}-\mathrm{AFP}$ ( Fig. 3, lane $B$ ), indicating that neither conjugation to the cross-linker nor the act of photoactivation altered AFP mobility. In addition, ${ }^{125}$ I-SASD-AFP when photoactivated ran identically under both reducing and nonreducing conditions.

In the proteoliposome reconstitution experiments, the most successful incorporation of the membrane proteins into liposomes was made when the lipid-to-protein ratio was 20:1 (wt:wt). The reconstituted "active" vesicles were recovered from SM-2 column rapidly and easily due to its typical opaque 


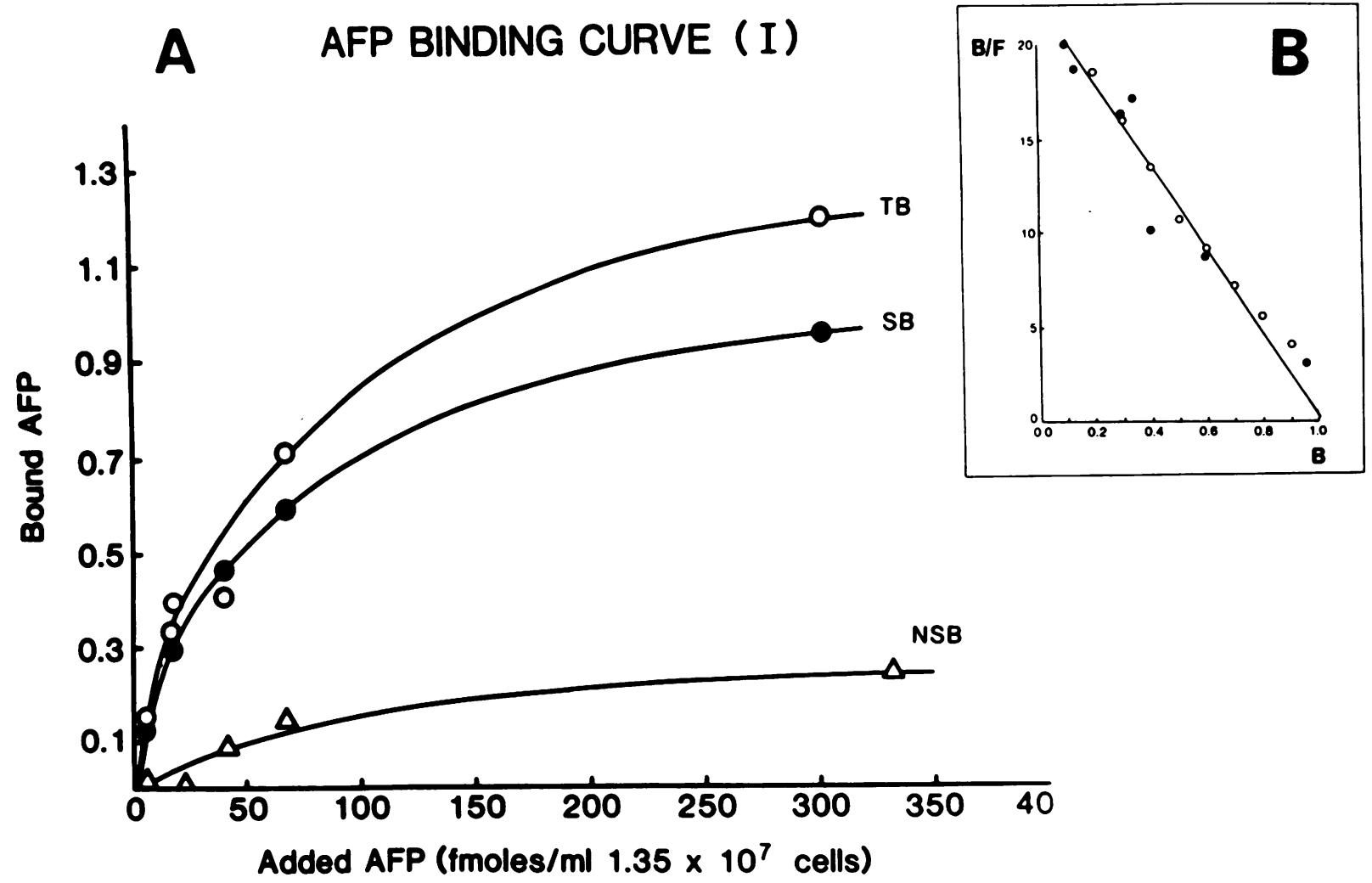

\section{AFP BINDING CURVE(II)}

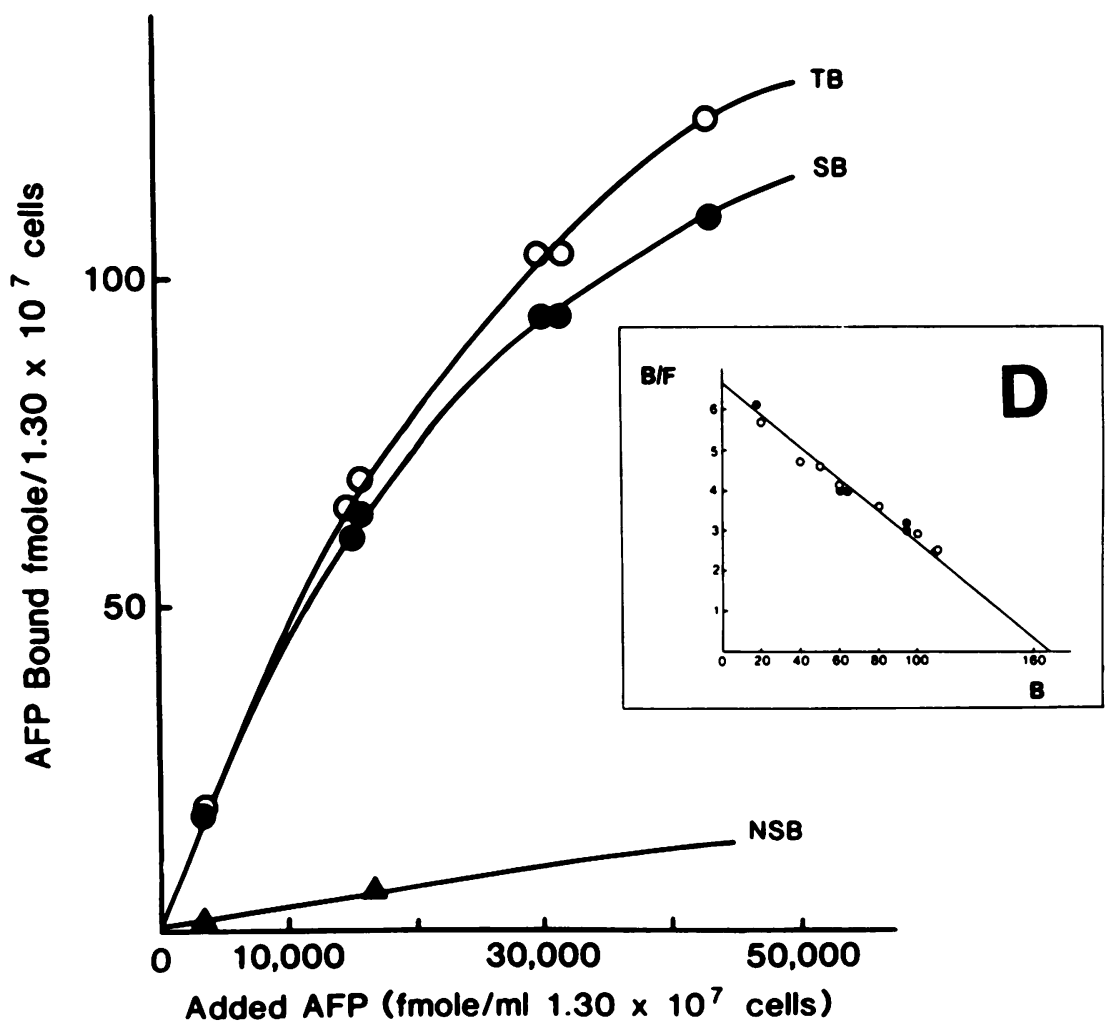

Figure 2. Binding kinetics of ${ }^{125}$ I-AFP to U937. U937 cells were incubated with various concentration of ${ }^{125}$ I-AFP in the presence or absence of 100 -fold excess of unlabeled purified AFP for $60 \mathrm{~min}$. The cells were sedimented in an oil mixture, and the radioactivity of the cell pellet was counted. The binding curve showed two saturation plateaus: plateau I ranged from $\sim 0.4$ to $6 \mathrm{ng} / \mathrm{ml}(A)$, with a $K_{\mathrm{d}}$ of $5 \times 10^{-11} \mathrm{M}$ and 49 binding sites per cell $(B)$; and plateau II ranged from $\sim 150$ to $300 \mathrm{ng} / \mathrm{ml}(C)$, with a $K_{\mathrm{d}}$ of $2.5 \times 10^{-7} \mathrm{M}$ and 7,800 binding sites per cell $(D)$. $T B$, Total binding; $S B$, specific binding; NSB, nonspecific binding. 


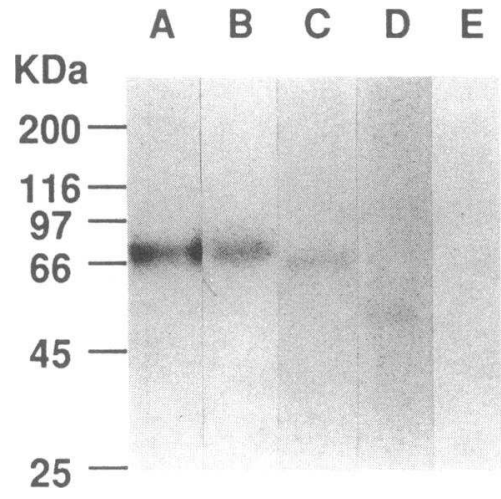

Figure 3. Autoradiogram of solubilized U937 cell lysate incubated with ${ }^{125}$ I-SASDAFP. $2 \times 10^{8}$ U937 cells were incubated with 50 $\mu \mathrm{g}{ }^{125} \mathrm{I}$-ASD-AFP for 30 min at room temperature, washed, photoactivated for 2 min with UV light, and solubilized with $0.5 \%$ Triton $\mathrm{X}-100$. The lysates were separated in $5-20 \%$ gradient SDS-PAGE fol-

lowed by autoradiography. Lane $A,{ }^{125}$ I-AFP; lane $B,{ }^{125}$ I-ASD-AFP, photoactivated, reducing condition; lane $C$, cell lysate, photoactivated, reducing condition; lane $D$, cell lysate, photoactivated, nonreducing condition; lane $E$, cell lysate, without photoactivation.

color in the void volume. The recombinant vesicles bound to the ligand were successfully separated from free ligand by gel filtration and eluted as the peak I of radioactivity in the void volume (Fig. $4 \mathrm{~A}$, open circle). After analysis by SDS-PAGE autoradiography, one aliquot from the peak I showed a major band at $\sim 62-65 \mathrm{kD}$ (Fig. $4 B$, lane $A$ ), while an aliquot from the peak II resulted in major band at $72 \mathrm{kD}$ (Fig. $4 B$, lane $B$ ), identical with that of control ${ }^{125} \mathrm{I}$-AFP (Fig. $4 B$, lane $C$ ).

\section{Discussion}

In this study, we demonstrated an obvious specific binding of purified AFP to human peripheral monocytes but not to resting lymphocytes. This result led us to pursue the characterization of this putative AFP receptor on U937 and THP-1 cell lines which retain many monocyte characteristics. The binding of AFP to the immunorecognition cell was first recognized on the rat peritoneal macrophage (18). Uriel and colleagues later demonstrated that normal lymphocytes do not bind AFP. However, blast-transformed or malignant lymphocytes specifically bound AFP and the binding kinetics were studied $(6,7)$. Therefore, AFP may bind to specific receptors on monocytes/macrophages as well as on activated $\mathrm{T}$ lymphocytes with malignant or blastic transformation, but not resting $\mathrm{T}$ lymphocytes. Our study of the binding kinetics to U937 in the present report indicates the presence of two distinct putative receptors activities: one with high affinity and low capacity $\left(K_{\mathrm{d}}\right.$ of $5 \times 10^{-11} \mathrm{M}$, 49 binding sites per cell) and the other with low affinity and high capacity $\left(K_{\mathrm{d}}\right.$ of $2.5 \times 10^{-7} \mathrm{M}, 7,800$ binding sites per cell). Similar data were obtained in a second monocyte-derived cell line, THP-1. A similar group of AFP binding sites with high affinity and low capacity, was also reported previously on rat peritoneal macrophages $\left(K_{\mathrm{d}}\right.$ of $2.5 \times 10^{-12} \mathrm{M}$ and 10 binding sites per cell) (18). Naval et al. evaluated three AFP binding sites in a murine T lymphoma cell line $\left(K_{\mathrm{d}}\right.$ of $2.2 \times 10^{-9} \mathrm{M}, 8.6$ $\times 10^{-7} \mathrm{M}$, and $5.7 \times 10^{-6} \mathrm{M}$, and $700,210,000$, and 910,000 binding sites per cell, respectively) (6) and similar relatively low affinity and high capacity sites were characterized in human T lymphocytes with PHA blast formation $\left(K_{\mathrm{d}}\right.$ of 3.03 $\times 10^{-7} \mathrm{M}, 88,500$ binding sites per cell) (7). These kinetic data not only suggest a cell specificity but also suggest the presence of similar receptor groups in the two cell types that may be involved in different biological functions. In fact, Haberland
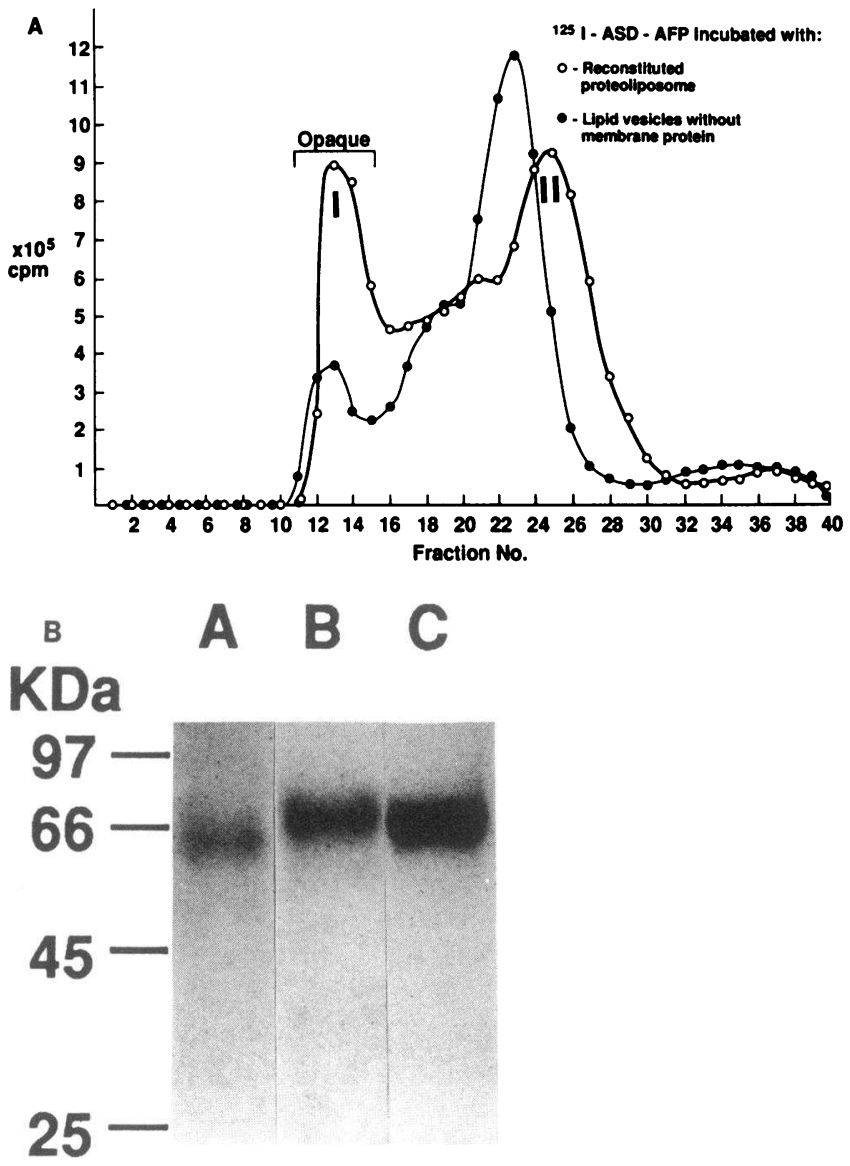

Figure 4. Recombination of ${ }^{125} \mathrm{I}-\mathrm{ASD}-\mathrm{AFP}$ with the isolated membrane receptor in semiartificial membrane vesicles. Crude membrane fractions of U937 cells were solubilized with $2 \%$ sodium cholate, $2 \%$ soybean lecithin in PBS and were applied to Bio-Beads SM-2 column to remove detergent. The reconstituted membrane vesicles were collected and immediately incubated with ${ }^{125} \mathrm{I}-\mathrm{ASD}-\mathrm{AFP}$ for $60 \mathrm{~min}$ at $4^{\circ} \mathrm{C}$, then bound and free ligands were separated by Sephadex G200 column. After photoactivation and subsequent counting of the radioactivity of each fraction, some of the eluates were selected and analyzed by SDS-PAGE autoradiography. $(A)$ Gel filtration of the recombinant reconstituted membrane vesicles (open circles) and liposomes without membrane proteins (closed circles) incubated with ${ }^{125}$ I-ASD-AFP. (B) Reconstitution of receptor proteoliposome with ${ }^{125}$ I-ASD-AFP. Autoradiogram of solubilized recombinant vesicles incubated with ${ }^{125}$ I-ASD-AFP. Lane $A$, An aliquot of the void volume peak I of the radioactivity (recombinant vesicles); lane $B$, an aliquot of the peak II of the radioactivity (free ligand); lane $C$, purified ${ }^{125} \mathrm{I}$ AFP.

and colleagues have also demonstrated the presence of two distinct binding sites for denatured proteins on human monocytes/macrophages. One site recognized maleyl-albumin and functions in monocyte chemotaxis. The other site recognized modified LDL and may correspond to the scavenger activity $(29,30)$. This was confirmed recently on murine peritoneal macrophages (45). Our results indicating that both monocyte cell lines (U937, THP-1) showed two distinct binding sites suggest the possibility that they may also serve separate functions. The first site is in the range of normal adult serum AFP $(<10$ $\mathrm{ng} / \mathrm{ml}$ ). The other site is in the range of elevated AFP levels found in fetal gestation as well as in certain malignant conditions which produce AFP in high concentration. These data 
suggest a hypothesis that the two groups of putative receptors specific for AFP may be involved with both physiological, and pathophysiological regulation of the immune response. In this respect, the AFP receptors are both functionally and biochemically unlike the scavenger receptors on monocytes/macrophages which recognize modified forms of LDL or chemically altered albumin $(30,46-48)$.

We have isolated the AFP receptor for the first time and demonstrated it to have a molecular mass of $\sim 65 \mathrm{kD}$ by SDSPAGE. The radiolabeled receptor consisted of a single band on SDS-PAGE at $\sim 50 \mathrm{kD}$ under nonreducing conditions (Fig. 3 , lane $D$ ). This slightly fast moving band appeared to be smaller than the receptor isolated under reducing conditions. This phenomenon can be partially explained if the receptor contained a globular structure maintained by disulfide bonds, such that it runs faster in nonreducing gels than that under reducing conditions as previously demonstrated $(24,49)$. This requires further elucidation.

The advantage of SASD and its usefulness for receptor identifications have been well documented previously $(24,40$, $50)$. SASD, a heterobifunctional photoactivatable thio-cleavable cross-linker, can be iodinated and conjugated with a ligand protein. After photoactivation, the complex covalently binds to adjacent membrane proteins while remaining radioactive labeled. Therefore, if the receptor has sufficient affinity to bind the ligand, the radiolabeled receptor alone can be finally separated in SDS-PAGE under reducing conditions. Nevertheless, several disadvantages also were discussed by Sorensen et al. (24). First, direct radioiodination of the ligand may take place during the conjugation step. We noted that a trace level of ${ }^{125} \mathrm{I}$-AFP was occasionally included in ${ }^{125} \mathrm{I}$-ASD-AFP working solution, probably because of the contamination of tiny Iodogen flakes into the vial. This was easily recognized and the preparation discarded. Secondly, either intra- or intermolecular cross-linking of the ligand may occur during photoactivation. Thus, ${ }^{125}$ I-ligand can be separated in the gel in addition to the receptor protein. To distinguish the specific band from those secondary by-products, ${ }^{125} \mathrm{I}$-ASD-AFP alone was photoactivated in advance and run in the gel as one of the controls. The isolated receptor was clearly distinct from either crosslinked SASD-AFP or AFP alone.

In general, the yields of receptor purification should mainly be due to the number of the cells used and the density of specific binding sites on each cell. For example, Ghinea et al. reported the identification of a putative albumin receptor using SASD from the rat microvascular endothelial cells and achieved a radioactive band on ligand blotting on a nitrocellulose membrane, in spite of strongly denaturing conditions (40). This was probably due to an extremely high density of albumin binding sites on those cells which had been estimated to be $3 \times 10^{6}$ sites per cell by Schnitzer et al. (51). In the present study, we had to minimize the proteolytic degradation (52), use nondenaturing conditions as well as high resolution SDS-PAGE (42), because the estimated number of receptors in U937 was lower.

In these studies, we also found that the receptor-ligand complex could not be precipitated by adding an appropriate amount of anti-AFP antibody, nor removed by anti-AFP affinity column chromatography (data not shown). This suggests that the antigenic epitope of AFP may localize closely to its receptor binding sites or they have a partially common structure. This phenomenon has been previously reported with the antibody against IgG Fc receptor on human monocytes shown to inhibit the ligand-receptor binding (53).

To confirm the specificity of the putative receptor identified by SDS-PAGE, recombination of the receptor-ligand was examined in a semiartificial and more defined membrane environment, the proteoliposome reconstitution system. As described above, it is also advantageous for the receptor protein to minimize the time to be exposed to any detergent in the reconstitution step as well as in the following recombination step with the ligand. Therefore, detergent removal was performed by using SM-2 column instead of a prolonged dialysis. We found specific binding of AFP with the liposomes consisting of soybean lecithin, with membrane receptor.

A sharp, single band with high density was obtained at 65 $\mathrm{kD}$ which reconfirmed the specificity of the band obtained in the previous analytic study. Under these conditions, the ligand would not be subjected to degradation or recycling as compared with incubation with living cells. Recent unpublished data, using electron microscopic techniques in our laboratory, revealed that AFP is internalized into monocytes via typical receptor mediated endocytosis. Finally, we conclude that human monocytes possess specific AFP binding proteins on the membrane, a putative receptor, which may be involved with the physiological regulation of the immune response. This putative AFP receptor was biochemically characterized as having a molecular mass of $65 \mathrm{kD}$ and was confirmed in a reconstituted receptor proteoliposome system. Studies are in progress to determine the precise mechanism of how the receptor-ligand interaction mediates the reported changes in monocyte function.

\section{Acknowledgments}

The authors wish to thank Ms. Lina Ricci for assistance in the preparation of the manuscript.

\section{References}

1. Trojan, J., and J. Uriel. 1981. Immunocytochemical localization of alphafetoprotein (AFP) and serum albumin (ALB) in ecto-, meso- and endodermal tissue derivatives of the developing rat. Oncodev. Biol. Med. 3:13-20.

2. Suzuki, Y., H. Taga, H. Ishizuki, H. Kaneda, T. Honda, and H. Hirai. 1983. Immunohistochemical study of $\alpha$-fetoprotein in rat embryos during ontogenesis. Ann. NY Acad. Sci. 417:224-239.

3. Uriel, J., C. Failly-Crepin, M. J. Villacampa, A. Piniero, and M. Geuskens. 1984. Incorporation of alpha-fetoprotein by the MCF-7 human breast cancer cell line. Tumor Biol. 5:41-51.

4. Laborda, J., J. Naval, M. Allouche, M. Calvo, V. Georgoulias, Z. Mishal, and J. Uriel. 1987. Specific uptake of alpha-fetoprotein by malignant human lymphoid cells. Int. J. Cancer. 40:314-318.

5. Uriel, J., J. Naval, and J. Laborda. 1987. Alpha-fetoprotein-mediated transfer of arachidonic acid into cultured cloned cells derived from a rat rhabdomyosarcoma. J. Biol. Chem. 262:3579-3585.

6. Naval, J., M. Villacampa, A. Goguel, and J. Uriel. 1985. Cell-type-specific receptors for alpha-fetoprotein in a mouse T-lymphoma cell line. Proc. Natl. Acad. Sci. USA. 82:3301-3305.

7. Torres, J. M., J. Laborda, J. Naval, N. Darracq, M. Calvo, Z. Mishal, and J. Uriel. 1989. Expression of alpha-fetoprotein receptors by human T-lymphocytes during blastic transformation. Mol. Immunol. 26:851-857.

8. Cohen, B. L., A. Orn, K.-O. Gronvik, M. Gidlund, H. Wigzell, and R. A Murgita. 1986. Suppression by alpha-fetoprotein of murine natural killer cell activity stimulated in vitro and in vivo by interferon and interleukin 2 . Scand. J. Immunol. 23:211-223.

9. Murgita, R. A., E. A. Goidl, S. Kontiainen, and H. Wigzell. 1977. $\alpha$-Fetoprotein induces suppressor T cells in vitro. Nature (Lond.). 267:257-259.

10. Alpert, E., J. L. Dienstag, S. Sepersky, B. Littman, and R. Rocklin. 1978 Immunosuppressive characteristics of human AFP: effect on tests of cell mediated immunity and induction of human suppressor cells. Immunol. Commun. $7: 163-185$. 
11. Peck, A. B., R. A. Murgita, and H. Wigzell. 1982. Cellular and genetic restrictions in the immunoregulatory activity of $\alpha$-fetoprotein. III. Role of the MLC-stimulating cell population in $\alpha$-fetoprotein-induced suppression of T cellmediated cytotoxicity. J. Immunol. 128:1134-1140.

12. Murgita, R. A., and T. B. Tomasi, Jr. 1975. Suppression of the immune response by $\alpha$-fetoprotein. II. The effect of mouse $\alpha$-fetoprotein on mixed lymphocyte reactivity and mitogen-induced lymphocyte transformation. J. Exp. Med. 141:440-452.

13. Yachnin, S. 1976. Demonstration of the inhibitory effect of human alphafetoprotein on in vitro transformation of human lymphocytes. Proc. Natl. Acad. Sci. USA. 73:2857-2861.

14. Auer, I. O., and H. G. Kress. 1977. Suppression of the primary cell-mediated immune response by human alpha $a_{1}$-fetoprotein in vitro. Cell. Immunol. 30:173-179.

15. Littman, B. H., E. Alpert, and R. E. Rocklin. 1977. The effect of purified $\alpha$-fetoprotein on in vitro assays of cell-mediated immunity. Cell. Immunol. 30:35-42.

16. Peck, A. B., R. A. Murgita, and H. Wigzell. 1978. Cellular and genetic restrictions in the immunoregulatory activity of alpha-fetoprotein. I. Selective inhibition of anti-Ia-associated proliferative reactions. J. Exp. Med. 147:667683.

17. Olinescu, A., M. Laky, D. E. Popescu, A. Dumitrescu, and D. Ganea. 1978. The effect of alpha-fetoprotein on the immune response. III. Diminution of the phagocytosis capacity of macrophages cultured in vitro in the presence of mouse amniotic fluid or alpha-fetoprotein. Scand. J. Immunol. 8:397-401.

18. The Shanghai Coordinating Group. 1979. Studies on alpha-fetoprotein v. influence of alpha-fetoprotein on immunological function. In Advances in Medical Oncology, Research, and Education. Biological Basis for Cancer Diagnosis. M. Fox, editor. Pergamon Press, New York. 297-301.

19. Lu, C. Y., P. S. Changelian, and E. R. Unanue. 1984. $\alpha$-fetoprotein inhibits macrophage expression of Ia antigens. J. Immunol. 132:1722-1727.

20. Crainie, M., A. Semeluk, K. C. Lee, and T. Wegmann. 1989. Regulation of constitutive and lymphokine-induced la expression by murine $\alpha$-fetoprotein Cell. Immunol. 118:41-52.

21. Anderson, C. L. 1982. Isolation of the receptor for $\mathrm{IgG}$ from a human monocyte cell line (U937) and from human peripheral blood monocytes. J. Exp. Med. 156:1794-1806.

22. Looney, R. J., G. N. Abraham, and C. L. Anderson. 1986. Human monocytes and U937 cells bear two distinct Fc receptors for IgG. J. Immunol. 135:1641-1647.

23. Uhl, J., R. C. Newton, J. G. Giri, G. Sandlin, and R. Horuk. 1989. Identification of Il-1 receptors on human monocytes. J. Immunol. 142:1576-1581.

24. Sorensen, P., N. M. Farber, and G. Krystal. 1986. Identification of the interleukin-3 receptor using an iodinatable, cleavable, photoreactive cross-linking agent. J. Biol. Chem. 261:9094-9097.

25. Crowell, R. E., T. W. DuClos, G. Montoya, E. Heaphy, and C. Mold. 1991. C-reactive protein receptors on the human monocyte cell line U-937. $J$. Immunol. 147:3445-3451.

26. Imamura, K., D. Spriggs, and D. Kufe. 1987. Expression of tumor necrosis factor receptors of human monocytes and internalization of receptor bound ligand. J. Immunol. 139:2989-2992.

27. Spiegelberg, H. L. 1984. Structure and function of Fc receptors for IgE on lymphocytes, monocytes, and macrophages. Adv. Immunol. 35:61-68.

28. Speigelberg, H. L., F. M. Melewicz, and N. R. Ferreri. 1986. IgE Fc receptors and monocytes and allergy. Ann. Inst. Pasteur Immunol. 137C:358363.

29. Haberland, M. E., R. R. Rasmussen, C. L. Olch, and A. M. Fogelman. 1986. Two distinct receptors account for recognition of maleyl-albumin in human monocytes during differentiation in vitro. J. Clin. Invest. 77:681-689.

30. Haberland, M. E., R. R. Rasmussen, and A. M. Fogelman. 1986. Receptor recognition of maleyl-albumin induces chemotaxis in human monocytes. J. Clin. Invest. 78:827-831.

31. Andreesen, R., J. Osterholz, H. Bodemann, K. J. Bross, U. Costabel, and G. W. Lohr. 1984. Expression of transferrin receptors and intracellular ferritin during terminal differentiation of human monocytes. Blut. 49:195-202.

32. Kataoka, M., and M. Tavassoli. 1985. Identification of ceruloplasmin receptors on the surface blood monocytes, granulocytes, and lymphocytes. Exp. Hematol. (NY). 13:806-810.
33. Kirchheimer, J. C., and H. G. Remold. 1989. Endogenous receptor-bound urokinase mediates tissue invasion of human monocytes. J. Immunol. 143:26342639.

34. Frey, J., and W. Engelhardt. 1987. Characterization and structural analysis of Fc receptors of human monocytes, a monoblast cell line (U937) and a myeloblast cell line (HL-60) by a monoclonal antibody. Eur. J. Immunol. 17:583-591.

35. Polgar, K., G. Abel, S. Sipka, and Z. Papp. 1988. Neutral-red uptake and expression of monocytic antigens in amniotic-fluid mononuclear phagocytes: evaluation of a novel approach for prenatal diagnosis of neural-tube defects. $\mathrm{Am}$. J. Reprod. Immunol. Microbiol. 18:81-86.

36. Trojan, J., J. Naval, H. Jusforgues, and J. Uriel. 1989. Alpha-fetoprotein (AFP) in granulomatous inflammation of the mouse. Br. J. Exp. Pathol. 70:469478.

37. Fraker, P. J., and J. C. Speck, Jr. 1978. Protein and cell membrane iodinations with a sparingly soluble chloroamide, 1,3,4,6-tetrachloro-3a, 6a-diphenylglycoluril. Biochem. Biophys. Res. Commun. 80:849-857.

38. Stein, G. H., and R. Yanishevsky. 1979. Autoradiography. Methods Enzymol. 58:279-292.

39. Haigler, H. T., F. R. Maxfield, M. C. Willingham, and I. Pastan. 1980. Dansylcadaverine inhibits internalization of ${ }^{125} \mathrm{I}$-epidermal growth factor of BALB 3T3 cells. J. Biol. Chem. 255:1239-1241.

40. Ghinea, N., M...Eskenasy, M. Simionescu, and N. Simionescu. 1989. Endothelial albumin binding proteins are membrane-associated components exposed on the cell surface. J. Biol. Chem. 264:4755-4758.

41. Laemmli, U. K. 1970. Cleavage of structural proteins during the assembly of the head of bacteriophage T4. Nature (Lond.). 227:680-685.

42. Mohamed, M. A., K. A. Lerro, and G. D. Prestwich. 1989. Polyacrylamide gel miniaturization improved protein visualization and autoradiographic detection. Anal. Biochem. 177:287-290.

43. Shimizu, S., and I. Funakoshi. 1970. Carbohydrate composition of the plasma membranes of rat ascites hepatoma. Biochim. Biophys. Acta. 203:167169

44. Kagawa, Y., and E. Racker. 1971. Partial resolution of the enzymes catalyzing oxidative phosphorylation. XXV. Reconstitution of vesicles catalyzing ${ }^{32} \mathrm{P} 1$-adenosine triphosphate exchange. J. Biol. Chem. 246:5477-5487.

45. Haberland, M. E., C. S. Tannenbaum, R. E. Williams, D. O. Adams, and T. A. Hamilton. 1989. Role of the maleyl-albumin receptor in activation of murine peritoneal macrophages in vitro. J. Immunol. 142:855-862.

46. Goldstein, J. L., Y. K. Ho, S. K. Basu, and M. S. Brown. 1979. Binding site on macrophages that mediates uptake and degration of acetylated low density lipoprotein, producing massive cholesterol deposition. Proc. Natl. Acad. Sci. USA. 76:333-337.

47. Brown, M. S., S. K. Basu, J. R. Falck, Y. K. Ho, and J. L. Goldstein. 1980 The scavenger cell pathway for lipoprotein degradation: specificity of the binding site that mediates the uptake of negatively-charged LDL by macrophages. $J$. Supramol. Struct. 13:67-81.

48. Via, D. P., H. A. Dresel, S. L. Chang, and A. M. Gotto, Jr. 1985. Murine macrophage tumors are a source of a 260,000 -dalton acetyl-low density lipoprotein receptor. J. Biol. Chem. 260:7379-7386.

49. Iwanig, V., and K. C. Hur. 1985. Direct cross-linking of ${ }^{125}$ I-labeled glucagon to its membrane receptor by UV irradiation. Proc. Natl. Acad. Sci. USA. $82: 325-329$

50. Sherphard, E. G., F. C. de Beer, C. von Holt, and J. P. Hapgood. 1988. The use of sulfosuccinimidyll-2-( $p$-azidosalicylamido)-1-3'-dithiopropionate as a crosslinking reagent to identify cell surface receptors. Anal. Biochem. 168:306313.

51. Schnitzer, J. E., W. W. Carley, and G. E. Palade. 1988. Specific albumin binding to microvascular endothelium in culture. Am. J. Physiol. 254:H425H437.

52. Umezama, K., and T. Aoyagi. 1984. Elimination of protein degradation by use of protease inhibitors. In Receptor Purification Procedures. Receptors Biochemistry and Methodology. J. C. Venter and L. C. Harrison, editors. Alan R. Liss, Inc., New York. 139-148.

53. Anderson, C. L., J. M. Spence, T. S. Edwards, and J. Nusbacher. 1985. Characterization of a polyvalent antibody directed against the IgG Fc receptor of human mononuclear phagocytes. J. Immunol. 134:465-470. 